\title{
PENGEMBANGAN NILAI MORAL ANAK MELALUI METODE BERCERITA PADA KELOMPOK B DI TK PEMBINA KOTA KENDARI
}

\author{
Mansyur M \\ Dosen Jurusan Pendidikan Guru Sekolah Dasar FKIP UHO \\ Email : mansyur735@yahoo.com
}

\begin{abstract}
ABSTRAK. Penelitian ini berawal dari permasalahan rendahnya kemampuan nilai moral dalam bercerita yang ditandai pada saat anak melakukan aktifitas. Dari hasil belajar anak menunjukan bahwa, dari 20 orang anak hanya $40 \%$ yang memiliki nilai moral yang baik dalam bercerita dengan kriteria berkembang baik (BB). Hal ini menunjukan bahwa hasil belajar dalam mengembangkan nilai moral anak belum mencapai kriteria ketuntasan minimal (KKM) yang ditetapkan oleh TK Negeri Pembina Kota Kendari, yaitu 70\% sesuai dengan hasil wawancara pada tanggal 10 Mei 2016.

Rumusan masalah dalam penelitian ini adalah: Bagaimana mengembangkan Nilai moral Anak melalui Metode bercerita pada kelompok B TK Pembina Kota Kendari. Tujuan yang di harapkan dari penelitian ini adalah untuk mengembangkan nilai moral anak melalui metode bercerita pada kelompok B TK Pembina Kota Kendari. Setelah dilakukan penelitian ini, diharapkan dapat memberikan manfaat: (1) bagi anak, dapat mengembangkan hasil belajar nilai moral Anak melalui Metode bercerita pada kelompok B TK Pembina Kota Kendari; (2) bagi guru dan sekolah dapat memperbaiki kinerjanya dalam pembelajaran, karena melalui penelitian tindakan kelas guru dapat mengetahui kelemahan-kelemahan yang terjadi dalam pembelajaran dan akan berusaha memperbaikinya pada proses pembelajaran berikutnya; dan (3) bagi peneliti, dapat digunakan sebagai bahan masukan untuk merumuskan kebijakan yang mengarah pada peningkatan hasil belajar anak khususnya di TK Pembina Kota Kendari. Disamping itu, dengan adanya penelitian tindakan kelas yang dilakukan oleh guru akan mengembangkan mutu pembelajaran di Taman kanak-kanak tersebut.

Metodelogi penelitian yang digunakan adalah Penelitian Tindakan Kelas (Classroom Action research). Penelitin ini dilaksanakan dalam dua siklus. Tahap-tahap dalam penelitian ini mengikuti prosedur penelitian tindakan kelas, yaitu: (1) perencanaan, (2) pelaksanaan, (3) observasi atau pengamatan, dan (4) refleksi. Berdasarkan analisis data hasil observasi aktivitas mengajar guru pada siklus I diperoleh persentase ketercapaian sebesar 80\%. Sedangkan aktivitas belajar anak diperoleh persentase ketercapaian sebesar 70\%. Pada siklus II, persentase ketercapaian aktivitas mengajar guru mengalami peningkatan menjadi $90 \%$. Sedangkan persentase ketercapaian aktivitas belajar anak juga mengalami peningkatan menjadi $85 \%$. Sehingga dapat dikatakan bahwa nilai moral Anak melalui Metode bercerita pada kelompok B TK Pembina Kota Kendari berkembang sesuai dengan harapan.
\end{abstract}

Kata Kunci : Nilai moral Anak, Konsep Pengembang moral, Metode bercerita.

\section{PENDAHULUAN}

Pendidikan anak usia dini adalah suatu upaya pembinaan yang ditujukan kepada anak sejak lahir sampai dengan usia enam tahun yang dilakukan melalui pemberian rangsangan pendidikan untuk membantu pertumbuhan dan perkembangan jasmani dan rohani agar anak memiliki kesiapan dalam memasuki pendidikan lebih lanjut (UU Nomor 20 Tahun 2003 Tentang Sistem Pendidikan Nasional, Pasal 1 Ayat 14) dalam (Oding Supriadi, 2010: 75). Pendidikan anak usia dini diselenggarakan sebelum jenjang pendidikan dasar (Pasal 28 UU Nomor 20 Tahun 2003 Tentang Sistem Pendidikan Nasional). Anak usia dini adalah sosok individu yang sedang 
menjalani suatu proses perkembangan dengan pesat dan fundamental bagi kehidupan selanjutnya. Pada masa ini proses pertumbuhan dan perkembangan dalam berbagai aspek sedang mengalami masa yang cepat dalam rentang perkembangan hidup manusia.

Pola asuh yang baik sejak dini akan besar pula pengaruhnya bagi tumbuh kembang seorang anak, terutama dari lingkungan terdekat anak. Lingkungan terdekat ini meliputi keluarga dan budaya serta kehidupan sosial yang berkembang dan berlangsung disekitarnya, tempat dimana anak dibesarkan. Hal ini akan menjadi modal awal bagi anak untuk belajar berkomunikasi, bersosialisasi serta untuk menyalurkan energinya, mengekspresikan emosinya dan mengembangkan kreativitasnya.

Aspek perkembangan anak yang dikembangkan di taman kanak-kanak meliputi moral dan nilai-nilai agama, sosial emosional, bahasa, kognitif, fisik motorik. Aspek tersebut dikembangkan, sehingga menjadi kebiasaan yang positif. Seluruh aspek perkembangan tersebut dikembangkan melalui pembelajaran sehari-hari di taman kanak-kanak dengan cara yang menyenangkan dan bermain. Taman kanak-kanak merupakan pendidikan anak usia dini dalam jalur formal.
Nilai Moral merupakan salah satu aspek harus dicapai dalam tujuan pembelajaran termasuk aspek berbahasa dengan melalui bercerita. Bercerita di Taman kanak-kanak (TK) tidak hanya terkait dengan mengembangkan kemampuan berbahasa, kognitif saja, tetapi juga kesiapan nilai moral atau mental, dan sosial emosional tersebut dalam pelaksanaan pembelajaran. Hal ini agar dapat menumbuh kembangkan kemampuan berbahasa dan memiliki sikap moral anak terus berkembang.

Perkembangan nilai moral anak ditandai dengan kemampuan anak untuk memahami aturan, norma, dan etika yang berlaku (Slamet Suyanto, 2005:67). Mengingat moralitas merupakan faktor penting dalam kehidupan manusia maka manusia sejak dini harus mendapatkan pengaruh yang positif untuk menstimulasi perkembangan moralnya, termasuk ketika anak bercerita.

Melalui kegiatan bercerita menjadikan anak akan memperoleh pengetahuan bagaimana cara menyampaikan pesan secara santun pada orang lain agar orang lain mampu memahami pesan-pesan yang akan disampaikan. Menurut Yuliani Nurani Sujiono, dkk (2006:7-9), metode bercerita adalah menyampaikan sesuatu dengan tutur atau memberikan penjelasan lisan melalui cerita. Kejadian atau suatu peristiwa disampaikan kepada peserta 
didik melalui tutur kata, ungkapan dan mimik wajah yang santun, sehingga nampak terlihat nilai moral yang baik.

Berdasarkan hasil observasi di TK Pembina Kota Kendari, diperoleh informasi ada sebagian anak khususnya pada kelompok B yang kurangnya kemampuan nilai moral dalam bercerita yang ditandai pada saat anak melakukan aktifitas. Dari hasil belajar anak menunjukan bahwa, dari 20 orang anak hanya $40 \%$ yang memiliki nilai moral yang baik dalam bercerita dengan kriteria berkembang baik (BB). Hal ini menunjukan bahwa hasil belajar dalam mengembangkan nilai moral anak belum mencapai kriteria ketuntasan minimal (KKM) yang ditetapkan oleh TK Pembina Kota Kendari, yaitu $70 \%$ sesuai dengan hasil wawancara tanggal 10 Mei 2016.

Perkembangan nilai moral anak melalui metode bercerita dengan menerapkan pendekatan agar dapat mengembangkan kemampuan berpikir untuk mengoptimalkan potensi yang dimiliki oleh anak usia dini agar merekah tumbuh dan berkembang sesuai dengan potensi yang dimiliki. Sehingga perlu dilakukan suatu upaya yang kreatif agar mereka dapat tumbuh dan berkembang secara optimal dengan keadaan yang nyaman, menyenangkan dan bermakna dalam diri anak. Upaya-upaya tersebut dapat dilakukan oleh pendidik melalui metode bercerita agar anak dapat mengembangkan kemapuan nilai moral pada kelompok B TK Pembina Kota Kendari. Dalam mengembangkan metode bercerita pada anak usia dini tidak lepas dari faktor belajar sambil bermain. Karena belajar sambil bermain merupakan tuntutan dan kebutuhan esensial bagi anak usia dini. Kegiatan belajar sambil bermain melalui metode bercerita anak dapat mengembangkan nilai moral tentang diri mereka sendiri, orang lain, lingkungan dan belajar bagaimana cara mereka untuk bisa berinteraksi dalam bekerja sama dan saling membatu satu sama lain.

Berdasarkan uraian tersebut, maka penulis merasa perlu melakukan penelitian dengan judul "Mengembangkan Nilai moral Anak melalui Metode bercerita pada kelompok B TK Pembina Kota Kendari.

\section{Definisi Nilai Moral}

\section{Pengertian Moral}

Menurut Hurlock, (Yusuf,2002:7). istilah moral berasal dari kata latin mos (moris), yang berarti adat istiadat, kebiasaan, peraturan/nilai-nilai atau tata cara kehidupan. Sedangkan moralitas merupakan kemauan untuk menerima dan melakukan peraturan, nilai- nilai atau prinsip-prinsip moral.

Dengan makin bertambahnya tingkat pengetahuan, makin banyak pula nilai-nilai moral. Menurut Hurlock (Sianawati,dkk, 1992:24) meskipun perkembangan peserta 
didik melewati pentahapan yang tetap, namun usia mereka dalam mencapai tahapan tertentu berbeda menurut tingkat perkembangan kognitif mereka. Menurut Gunarsa (1989:62) keluarga merupakan lingkungan kehidupan yang dikenal anak untuk pertama kalinya, dan untuk seterusnya anak banyak belajar di dalam kehidupan keluarga. Karena itu peranan orang tua dianggap paling besar pengaruhnya terhadap perkembangaan moral seorang anak.

Pengembangan moral anak usia dini dilakukan agar terbentuk perilaku moral. Pembentukan perilaku moral pada anak, khususnya pada anak usia dini memerlukan perhatian serta pemahaman terhadap dasar-dasar serta berbagai kondisi yang mempengaruhi dan menentukan perilaku moral. Ada tiga strategi dalam pembentukan perilaku moral pada anak usia dini, yaitu: strategi latihan dan pembiasaan, strategi aktivitas dan bermain, dan strategi pembelajaran (Wantah, 2005:109).

\section{Konsep Pengembangan Moral Anak}

\section{Usia Dini}

Menurut Megawangi, dalam Siti Aisyah dkk. (2007: 8.36), anak-anak akan tumbuh menjadi pribadi yang berkarakter apabila mereka berada di lingkungan yang berkarakter pula. Usaha mengembangkan anak-anak agar menjadi pribadi-pribadi yang bermoral atau berkarakter baik merupakan tangguang jawab keluarga, sekolah, dan seluruh komponen masyarakat. Usaha tersebut harus dilakukan secara terencana, terfokus, dan komprehensif. Pengembangan moral anak usia dini melalui pengembangan pembiasaan berperilaku dalam keluarga dan sekolah.

\section{a. Pengembangan berperilaku yang} baik dimulai dari dalam keluarga

Keluarga merupakan lingkungan pertama dan utama bagi perkembangan anak. Keluarga merupakan lingkungan pendidikan pertama dan paling efektif untuk melatih berbagai kebiasaan yang baik pada anak.

Menurut Thomas Lickona, sebagimana pendapatnya dikutip oleh Siti Aisyah dkk. (2007: 8.38 - 8.41), ada 10 hal penting yang harus diperhatikan dan dijadikan prinsip dalam mengembangkan karakter anak dalam keluarga, yaitu sebagai berikut.

1) Moralitas penghormatan

Hormat merupakan kuci utama untuk dapar hidup harmonis dengan masyarkat. Moralitas penghormatan mencakup: (a) penghormatan kepada diri sendiri untuk mencegah agar diri sendiri tidak terlibat dalam perilaku yang merugikan diri sendiri; (b) penghormatan kepada sesama manusia meskipun berbeda suku, agama, kemampuan ekonomi; (c) penghormatan 
kepada lingkungan fisik yang merupakan ciptaan Tuhan.

2) Perkembangan moralitas kehormatan berjalan secara bertahap

Anak-anak tidak bisa langsung berkembang menjadi manusia yang bermoral, tetapi memerlukan waktu dan proses yang terus menerus, dan memerlukan kesabaran orang tua untuk melakukan pendidikan tersebut.

3) Mengajarkan prinsip menghormati

Anak-anak akan belajar menghormati orang lain jika dirinya merasa bahwa pihak lain menghormatinya. Oleh karena itu orang tua hendaknya menghormati anaknya. Penghormatan orang tua kepada anak dapat dilakukan misalnya dengan menghargai pendapat anak, menjelaskan kenapa suatu aturan dibuat untuk anak, dst.

4) Mengajarkan dengan contoh

Pembentukan perilaku pada anak mudah dilakukan melalui contoh. Oleh karena itu contoh nyata dari orang tua bagaimana seharusnya anak berperilaku harus diberikan. Selain itu, orang tua juga bisa membacakan buku-buku yang di dalamnya terdapat pesan-pesan moral. Orang tua hendaknya mengontrol acaraacara televisi yang sering ditonton anaknya, jangan sampai acara yang disukai anak adalah acara yang berpengaruh buruk pada perkembangan moralnya.

5) Mengajarkan dengan kata-kata
Selain mengajar dengan contoh, orang tua hendaknya menjelaskan dengan kata-kata apa yang ia contohkan. Misalnya anak dijelaskan mengapa berdusta dikatakan sebagai tindakan yang buruk, karena orang lain tidak akan percaya kepadanya.

6) Mendorong anak unruk merefleksikan tindakannya Ketika anak telah melakukan tindakan yang salah, misalnya merebut mainan adiknya sehingga adiknya menangis, anak disuruh untuk berpikir jika ada anak lain yang merebut mainannya, apa reaksinya.

7) Mengajarkan anak untuk mengemban tanggung jawab. Anak-anak harus dididik untuk menjadi pribadi-pribadi yang altruistik, yaitu peduli pada sesamana. Untuk itu sejak dini anak harus dilatih melalui pemberian tanggung jawab.

8) Mengajarkan keseimbangan antara kebebasan dan kontrol

Keseimbangan antara kebebasan dan kontrol diperlukan pengembangan moral anak. Anak diberi pilihan untuk menentukan apa yang akan dilakukannya namun aturan-aturan yang berlaku harus ditaati.

9) Cintailah anak, karena cinta merupakan dasar dari pembentukan moral Perhatian dan cinta orang tua kepada anak merupakan kontribusi penting dalam pembentukan karakter yang baik pada anak. Jika anak-anak diperhatikan dan 
disayangi maka mereka juga belajar memperhatikan dan menyayangi orang lain.

10) Menciptakan keluarga bahagia

Pendidikan moral kepada anak tidak terlepas dari konteks keluarga. Usaha menjadikan anak menjadi pribadi yang bermoral akan lebih mudah jika jika anak mendapatkan pendidikan dari lingkungan keluarga yang bahagia. Untuk itu usaha mewujudkan keluarga yang bahagia merupakan syarat yang harus dipenuhi oleh orang tua sehubungan dengan erkembangan moral anaknya.

\section{b. Pengembangan kebiasaan}

\section{berperilaku yang baik di sekolah}

Perkembangan moral anak tidak terlepas dari lingkungan di luar rumah. Menurut Goleman (1997) dan Megawangi 2004) dalam Siti Aisyah dkk. (2007: 8.418.42), bahwa lingkungan sekolah berperan dalam pengembangan moral anak usia dini. Pendidikan moral pada lembaga pendidikan formal dimulai ketika anakanak mengikuti pendidikan pada taman kanak-kanak. Menurut Schweinhart (Siti Aisyah dkk., 2007: 8.42), pengalaman yang diperoleh anak-anak dari taman kanak-kanak memberikan pengaruh positif pada pada perkembangan anak selanjutnya.

Di lembaga pendidikan formal anak usia dini, peran pendidik dalam pengembangan moral anak sangat penting.
Oleh karena itu, menurut Megawangi (Siti Aisyah, 2007: 8.45), pendidik harus memperhatikan beberapa hal, yaitu sebagai berikut.

1) Memperlakukan anak didik dengan kasih sayang, adil, dan hormat.

2) Memberikan perhatian khusus secara individual agar pendidik dapat mengenal secara baik anak didiknya.

3) Menjadikan dirinya sebagai contoh atau tokoh panutan.

4) Membetulkan perilaku yang salah pada anak didik, (Siti Aisyah, 2007: 8.45).

\section{Perkembangan Moral Melalui}

\section{Metode Bercerita}

Tadkiroatun Musfiroh, (2005: 75) Perkembangan moral anak dipengaruhi oleh perkembangan intelektual dan penalaran. Anak-anak belum dapat menerapkan secara optimal prinsip-prinsip yang abstrak yang menyangkut benar salah serta tatanan moral dan sosial yang lain. Hal ini, perlu latihan bagi mereka tentang bagaimana perilaku moral dalam konteks tertentu, dengan ditekankan pada bagaimana bertindak. Penanam moral pada masa kanak-kanak dengan berbagai cara, diantaranya dengan memberikan gambaran begaimana berperilaku moral diterima dan didukung melalui cerita. Selanjunnya Tadkiroatun Musfiroh, (2005:75), bahwa penanaman moral melalui cerita sangat mungkin dilakukan karena metode tersebut sesuai dengan perkembangan usia anak. 
Moral pada masa anak-anak tidak dipahami dalam arti sebenarnya (Tadkiroatun Musfiroh, 2005:75). Moralitas dipandang suatu yang konflik antara kepentingan diri dan lingkunganya, yaitu antara hak dan kewajiban oleh karena itu, cerita yang melibatkan pertarungan baik dan buruk dalam kehidupan menjadi "Pelajaran" moral yang cukup penting bagi anak. Cerita menjadi stimulus yang efektif mengenal perilaku moral karena konsep moral dalam cerita berada dalam dominan dapat dicerna oleh anak. Tadkiroatun Musfiroh, (2005:76), perkembangan moral anak dapat dirangsang melalui otoritas dalam cerita, yakni otoritas terhadap baik dan buruk.

Perkembangan moral anak harus diterapkan, yaitu: (a) berupa nilai etika dasar; (b) menyentuh aspek pikiran, perasaan, dan perilaku; (c) memiliki tempat untuk mempraktikkan; (e) operesional untuk diterapkan dalam kehidupan anak-anak; (f) memperoleh dukungan dari rumah dan sekolah; (g) sejalan dengan motivasi anak; dan (h) terdukung secara akademis melalui kurikulum (Wayan Kayon, 2000).

\section{Metode Bercerita}

\section{Pengertian Metode Bercerita}

Menurut Fadillah Muhammad (2012:174) metode bercerita merupakan salah satu metode pembelajaran anak usia dini yang dapat memberikan manfaat positif bagi perkembangan anak, terutama perkembangan moral, bahasa, dan sosialemosional. Senada Moeslichattoen (1996:112) mengatakan bahwa metode bercerita merupakan pemberian pengalaman belajar anak Taman Kanakkanak melelui cerita yang disampaikan secara lisan. Metode bercerita merupakan hal yang sangat penting dalam membangun aspek perkembangan bahasa anak di TK. Katika seorang anak mendengarkan suatu cerita, anak akan belajar mengembangkan kemampuan kognitif, nilai moral, tata berbicara, emosiaonal dan sosial. Metode bercerita merupakan salah satu pemberian pengalaman belajar bagi anak TK dengan membawakan cerita kepada anak secara lisan. Cerita yang dibawakan guru harus disesuai perkembangan anak TK. Fadillah Muhammad (2012:173) mengatakan, cerita adalah salah satu untuk menarik perhatian anak. Biasanya cerita yang disukai anak, yaitu cerita yang berkaitan dengan dunia binatang, seperti cerita Si Kancil ataupun sejenisnya.

Yuliani Nurani Sujiono, dkk (2006:7-9), metode bercerita adalah menyampaikan sesuatu dengan tuturan atau memberi penjelasan secara lisan melalui cerita. Cerita harus menarik, dengan tujuan yang ingin dicapai dengan gerak-gerak yang wajar dan intonasi yang bervariasi. Gunarti (2008:73), metode 
bercerita adalah suatu kegiatan yang dilakukan seseorang untuk menyampaikan sesuatu pesan, informasi atau sebuah dongeng belaka yang bisa dilakukan secara lisan atau tulis.

Dari segi bahasa, bercerita merupakan cara yang sangat baik untuk mengembangkan daya pemahaman bercerita, mendengarkan serta dapat menambah perbendaharaan kata-kata baru. Melalui cerita kata-kata dasar dalam pengembagan bahasa anak dapat menstimuluskan pemerolehan kata.

Tadkiroatun Musfiroh, (2005:8), perkembangan bahasa anak tergantung pada kematangan sel kortek, dukungan lingkungan, dan keterdidikan lingkungan. Beberapa hal dalam perkembangan bahasa anak adalah perkembangan persepsi, pengertian adaptasi, imitasi, dan ekspresi. Syarat penting lainnya adalah pendengaran yang baik untuk menangkap berbagai jenis nada bicara dan kemampuan untuk dapat merasakan nada emosi lawan bicara. Anak harus belajar mengerti semua proses ini, berusaha meniru dan kemudian baru mencoba mengekspresikan keinginan dan perasaannya. Menurut Tadkiroatun Musfiroh, (2005:8), perkembangan bahasa anak meliputi perkembangan fonologis (yakni mengenal dan memproduksi suara), perkembangan kosakata, perkembangan simantik atau makna kata, dan perkembangan prakmatik atau penguasaan bahasa untuk keperluan komunikasi.

\section{Teknik Bercerita}

Penerapan teknik bercerita dipengaruhi oleh kondisi pendengar dan kultut (budaya) yang melingkupi cerita. Menurut Tadkiroatun Musfiroh, (2005137) tekni mengandung pengertian daya upaya, usaha-usaha, atau cara-cara yang digunakan guru untuk mencapai tujuan langsung dalam melaksanakan kegiatan bercerita. Dalam bercerita ada beberapa cara yang dapat dilakukan guru adalah: (a) membaca langsung dari buku cerita; (b) menceritakan dongeng; (c) mendongeng merupakan cara bercerita yang meneruskan warisan budaya dari satu generasi kegenerasi berikutnya; (d) bercerita dengan menggunakan ilustrasi gambar dari buku; (e) guru dapat membuat gambar-gambar ilustrasi secara sendiri terhadap cerita-cerita yang panjang namun penyampaian gambar yang sedikit; (f) bercerita menggunakan papan flannel. Cara berikutnya hampir sama dengan bercerita dengan menggunakan ilustrasi gambara, yang membedakannya adalah bahan dan alat yang digunakan; (g) bercerita dengan menggunakan media boneka; dan (h) bercerita dengan menggunakan atau jari-jari.

Menurut Sobry Sutikno, 2014:45) teknik yang dapat diterapkan dalam bercerita, yaitu: (1) guru dapat membaca 
langsung dari buku; (2) Menggunakan ilustrasi dari buku gambar; menggunakan boneka; (4) bermain peran dalam suatu cerita; (5) bercerita dengan menggunakan jari-jari tangan; dan (6) bercerita sebaiknya dalam kelompok kecil untuk memudahkan guru mengontrol kegiatan yang berlangsung sehingga agar berjalan lebih efektif.

\section{Manfaat Bercerita}

Bagi anak-anak, cerita tidak sekedar memberi manfaat emosioonal tetapi juga membantu pertumbuhan mereka dalam berbagai aspek. Manfaat bercerita menurut Ecka W. Pramita (2010:50), bagi anak usia dini adalah sebagai berikut.

a. Membantu pembentukan pribadi dan moral anak

Cerita sangat efektif untuk mempengaruhi cara berpikir dan cara berperilaku anak karena mereka senang mendengarkan cerita, meski cerita tersebut sudah dibaca berulang-ulang, misalnya cerita "Si Kancil yang Cerdik" , Malin Kundang", "Cinderella" dan masih banyak lagi lainnya. Pengulangan imajinasi anak dan nilai kedekatan orang tua dengan anak membuat cerita menjadi lebih efektif untuk mempengaruhi cara berpikir mereka.

b. Menyalurkan kebutuhan imajinasi dan fantasi

Anak-anak membutuhkan penyaluran imajinasi dan fantasi tentang berbagai hal yang selalu muncul dalam pikirannya.
Masa usia Emas merupakan masa-masa aktif anak berimajinasi. Tak jarang anak bahkan "mengaran" cerita sehingga terkadang oleh orang tua dianggap sebagai kebohongan. Hal ini, menunjukkan bahwa sebenarnya imajinasi anak-anak sedang membutuhkan penyaluran, misalnya anak membutuhkan dongeng atau cerita.

c. Memacu kemampuan verbal anak

Cerita yang bagus tidak sekedar menghibur tetapi juga mendidik sekaligus merangsang perkembangan komponen kecerdasan linguistic yang paling penting yakni, kemampuan menggunakan bahasa untuk mencapai sasaran. Selama menyimak cerita, anak belajar bagaimana bunyi-bunyi yang bermakna diajarkan dengan benar, bagaimana kata-kata disusun secara logis dan mudah dipahami anak dan bagaimana hubungaban antar konteks berfungsi.

d. Merangsang minat menulis

Dengan dibiasakan mendengar cerita maka dengan sendirinya akan memancing rasa kebahasaan anak terutama anak yang gemar mendengar dan membaca cerita akan memiliki kemampuan berbicara dan menulisnya. Misalnya saja minat anak untuk menuliskan kegiatan hariannya.

e. Merangsang minat baca anak

Bercerita dengan media, menjadi stimulus yang efektif bagi anak TK, karena pada waktu itu minat baca pada anak mulai tumbuh. Minat itullah yang harus diberi 
lahan yang tepat, antara lain, memulai kegiatan bercerita. Menstimulasi minat baca anak lebih penting daripada mengajar mereka membaca, menstimulasi memberi efek yang menyenangkan, sedangkan mengajar seringkali justru membunuh minat baca anak, apalagi hal tersebut dilakukan secara paksa.

f. Membuka cakrawala pengetahuan anak.

Setiap anak pada hakikatnya sangat tertarik untuk mengenal dunia, karena dunia ini cenderung berkaitan dengan budaya dan identitas banyak orang, maka anak juga terterik untuk mengenal budaya dan rasa lain. Kegiatan bercerita dapat memperhalus wawasan dan berfikir anak, sebab dalam bercerita, anak mendapat tambahan pengalaman yang bisa jadi merupakan hal baru baginya, atau juga seandainya bukan merupakan hal baru yang pernah didapat atau dialaminya.

Dhieni, dkk (2001:66), manfaat bercerita bagi anak antara lain: (1) melatih daya serap atau daya tangkap anak, artinya anak dapat dirangsang untuk memahami isi dalam cerita tersebut; (2) melatih daya kosentrasi anak untuk memusatkan perhatiannya kepada seluruh cerita tersebut; (3) mengembangkan daya imajinasi; (4) bercerita memberikan pengalaman belajar untuk melatih mendengarkan atau pendengaran; (5) membantu perkembangan kemampuan berbahasa anak dalam hal berkomunikasi; (6) bercerita untuk menanamkan kepada anak tentang kejujuran, keramahan, ketulusan, dan perilaku positif.

Dapat disimpulkan bahwa melalui bercerita dapat mendorong perkembangan moral anak karena amantnya yang didasarkan dalam cerita berdasarkan pada konsep baik dan buruk, konsep kejujuran, keadilan, tingkah laku, dan bagaimana beretika. Hal ini, dilandasi oleh berbagai kaidah yang berkonteks, membina anak berpikir secara rasional tentang salah dan benar. Nilai-nilai moral dalam cerita anak diadaptasikan dari nilai-nilai dalam masyarakat. Cerita dapat dianggap sebagai "Pengajaran" salah benar serta realisasi nilai-nilai yang didasarkan pada pertimbangan afektif dan pengalaman. Hal ini sejalan dengan pendapat Ellis (1998:267) bahwa perkembangan moral membutuhkan akal budi dan pendekatan analisis untuk menggali kepercayaan terhadap nilai-nilai dan kaidah-kaidah.

\section{METODE PENELITIAN}

\section{A. Jenis Penelitian}

Jenis penelitian yang digunakan adalah Penelitian Tindakan Kelas (Classroom Action research). Penelitian tindakan kelas ini dilakukan dengan bercerita sebagai solusi tindakan dalam mengembangkan kemampuan nilai moral 
anak pada Kelompok B TK Pembina Kota Kendari.

Ekawarna (2013: 5), menjelaskan bahwa Penelitian Tindakan Kelas adalah penelitian tindakan (action research)yang dilaksanakan oleh guru di dalam kelasnya sendiri. Sedangkan menurut Suyadi (2012: 4), penelitian tindakan kelas merupakan pencermatan yang dilakukan oleh guru di dalam kelasnya sendiri melalui refleksi diri untuk memperbaiki profesinya sebagai guru sehingga hasil belajar anak didik terus meningkat. Lebih lanjut Wibawa (Dimyati, 2013: 116) menambahkan bahwa penelitian tindakan kelas merupakan penelitian yang mengangkat masalah-masalah aktual yang dihadapi oleh guru dilapangan.

\section{B. Setting Penelitian}

Setting penelitian yang dimaksud dalam penelitian ini menunjukan pada pengertian lokasi dan waktu dimana penelitian ini dilaksanakan. Penelitian ini telah dilaksanakan pada Kelompok B di TK Pembina Kota Kendari. Penelitian ini dilaksanakan di dalam kelas. Penelitian dilaksanakan pada semester ganjil tahun pelajaran 2015/2016.

\section{Subjek dan Partisipan yang Terlibat}

\section{Dalam Penelitian}

\section{Subjek Penelitian}

Subjek dalam penelitian ini adalah guru dan anak didik kelompok B TK Pembina Kota Kendari yang berjumlah 20 orang yang terdiri atas 7 orang perempuan dan 13 orang laki-laki.

\section{Partisipan yang Terlibat}

Partisipan yang terlibat dalam kegiatan penelitian adalah guru kelompok B TK Pembina Kota Kendari yang berperan sebagai observer. Sedangkan peneliti berperan sebagai guru kelompok B yang memberikan pembelajaran atau tindakan pada anak didik dengan metode bercerita.

\section{Faktor Yang Diteliti}

Adapun faktor-faktor yang diteliti dan diamati dalam penelitian ini ialah:

1. Faktor anak didik, untuk melihat aktivitas anak dalam bercerita dan melihat perkembangan kemampuan nilai moral anak.

2. Faktor guru, untuk melihat bagaimana guru menggunakan metode bercerita dalam mengembangkan kemampuan nilai moral anak pada kelompok B TK Pembina Kota Kendari.

\section{E. Prosedur Pelaksanaan Penelitian}

Menurut Kemmis dan Mc Tanggart (dalam Ekawarna, 2013: 20), penelitian tindakan dapat dipandang dalam suatu siklus spiral dari penyusunan perencanaan, pelaksanaan tindakan, pengamatan (observasi), dan refleksi yang selanjutnya diikuti dengan siklus spiral berikutnya. Berikut ini tahapan penelitian tindakan kelas adalah sbagai berikut:

\section{a. Perencanaan}


pada tahap perencanaan pada siklus I ini yaitu membuat skenario pembelajaran berupa rencana kegiatan harian $(\mathrm{RKH})$ yang mengacu pada pembelajaran mengembangkan kemampuan nilai moral melalui metode bercerita pada anak, menyiapkan alat atau media cerita untuk menigkatkan kemampuan nilai moral serta menyiapkan lembar observasi sebagai acuan untuk melihat keterlaksanaan proses pembelajaran sesuai dengan yang direncanakan.

\section{b. Pelaksanaan Tindakan}

Pada tahap ini meliputi pelaksanaan tindakan yang dilakukan oleh peneliti sedangkan guru TK bertindak sebagai pengamat (observer). Adapun pelaksanaan tindakan:

1. Peneliti menjelaskan cara memahami tema dalam cerita dan contoh sederhana kepada anak didik.

2. Implikasi penjelasan bagaimana mamahami nilai moral dalam isi cerita yang ditindak lanjuti oleh anak didik dengan melakukan kegiatan bercerita.

3. Posisi anak didik diatur dengan rapi agar bisa mengamati dan mengikuti kegiatan pembelajaran dengan baik.

4. Setelah posisi anak didik diatur sesuai dengan yang diharapkan, peneliti memulai kegiatan pembelajaran dengan bercerita.

c. Observasi dan Evaluasi
Kegiatan observasi dilakukan setiap kali pertemuan selama pelaksanaan tindakan dalam proses pembelajaran dengan menggunakan lembar observasi yang telah disiapkan. Pada tahap ini dilaksanakan pengamatan secara seksama mengenai aktivitas anak didik selama mengikuti proses pembelajaran metode bercerita guna mengembangkan kemampuan nilai moral anak. Selanjutnya pelaksanaan evaluasi dilaksanakan pada setiap akhir tindakan agar lebih mengetahui peningkatan kemampuan kemampuan nilai moral anak melalui metode bercerita.

\section{d. Refleksi}

Refleksi dilakukan untuk melihat proses pelaksanaan tindakan hasil belajar anak didik yang didapatkan dalam tahap observasi dan evaluasi melalui kegiatan yang dilaksanakan apakah telah memenuhi target yang sesuai dengan kriteria indikator kinerja. Berdasarkan hasil analisis ini dapat diketahui kelemahan atau kekurangan yang terjadi dari tindakan yang dilakukan pada setiap kegiatan pembelajaran. Dalam tahap ini, keunggulan-keunggulan dipertahankan dan kelemahan-kelemahan yang terjadi dapat diperbaiki pada siklus berikutnya. Karena hasil refleksi digunakan untuk menetapkan langkah-langkah lebih lanjut pada siklus berikutnya. 


\section{HASIL DAN PEMBAHASAN}

A. Hasil Penelitian

\section{Deskripsi Kegiatan Sebelum}

Tindakan

Sebelum kegiatan penelitian dilakukan, peneliti melakukan pertemuan awal dengan Kepala Sekolah TK Pembina Kota Kendari kelompok B, diperoleh data tenaga pengajar dan data siswa serta data guru TK Pembina Kelompok B sebagai berikut:

Tabel 4.1 Perhitungan Nilai Klasikal pada Observasi Awal

\begin{tabular}{lcc}
\hline \multicolumn{1}{c}{ Kategori } & $\begin{array}{c}\text { Jumlah } \\
\text { Anak }\end{array}$ & $\begin{array}{c}\text { Persentase } \\
(\mathbf{\%})\end{array}$ \\
\hline $\begin{array}{l}\text { Berkembang Sangat } \\
\text { Baik (BSB) }\end{array}$ & 2 & $10 \%$ \\
$\begin{array}{l}\text { Berkembang Sesuai } \\
\text { Harapan (BSH) }\end{array}$ & 6 & $30 \%$ \\
$\begin{array}{l}\text { Mulai Berkembang } \\
\text { (MB) }\end{array}$ & 7 & $35 \%$ \\
$\begin{array}{l}\text { Belum Berkembang } \\
\text { (BB) Jumlah }\end{array}$ & 5 & $25 \%$ \\
\hline \multicolumn{1}{c}{ Jo } & $\mathbf{1 0 0 \%}$ \\
\hline
\end{tabular}

Sumber: diolah dari data penelitian, 2015

Data hasil perhitungan pada tabel 4.1 tersebut, dapat dirumuskan bahwa secara klasikal peningkatan nilai moral anak melalui bercerita pada Kelompok B TK Pembina Kota Kendari saat terakhir penilaian, rata-rata anak memiliki perolehan nilai bintang (**) atau Mulai Berkembang (MB) yang diperoleh oleh 7 orang anak didik atau sebesar $35 \%$, dengan kata lain sebagian besar anak didik belum mampu memenuhi target ketercapaian dalam indikator kinerja dalam kagiatan penilaian sehingga hal ini perlu diberikan bantuan secara langsung dan bimbingan secara menyeluruh pada kegiatan tersebut. Tampak dalam penelitian ada 6 orang anak didik memperoleh nilai bintang $(* * *)$ atau Berkembang Sesuai Harapan (BSH) dengan persentase sebesar $30 \%$ dan 2 orang anak didik yang memperoleh nilai bintang $(* * * *)$ atau Berkembang Sangat Baik (BSB) dengan persentase sebesar 10\%, namun terdapat 5 orang anak didik yang memperoleh nilai bintang $(*)$ atau Belum Berkembang (BB) dengan persentase sebesar 25\%. Dengan demikian, Peneliti akan merumuskan kembali dengan guru Kelompok B untuk menerapkan kegiatan pembelajaran dalam rangka mengembangkan nilai moral anak melalui bercerita pada tindakan siklus I.

Hal ini, perlu dilakukan Penelitian Tindakan Kelas, sehingga dapat mengembangkan hasil belajar nilai moral anak melalui metode bercerita pada kelompok B TK Pembina Kota Kendari.

\section{B. Pembahasan}

Penelitian tindakan kelas merupakan suatau penelitian yang dilakukan oleh guru di dalam kelasnya sendiri melalui refleksi diri yang bertujuan untuk memperbaiki pembelajaran sehingga motorik anak didik meningkat. Pelaksanaan penelitian ini terdiri dari dua siklus, dimana setiap siklus terdiri atas empat kali pertemuan. Pada pelaksanaan pembelajaran tiap pertemuan menggunakan media teks cerita. Setiap pertemuan terdiri atas tiga tahap kegiatan yaitu kegiatan awal, kegiatan inti, dan kegiatan akhir. Kegiatan awal, yaitu kegiatan pendahuluan yang dilakukan guru sebelum masuk pada tema pembelajaran yang diawali dengan salam dan membaca doa, memotivasi anak didik serta memberikan apersepsi yang berhubungan dengan tema pembelajaran. 
Kegiatan inti, yaitu guru menjelaskan tujuan pembelajaran yang berhubungan dengan permainan bakiak. Guru membagi anak didik dalam tujuh kelompok, guru melalkukan kegiatan yang berhubungan dengan bakiak/bercerita dihalaman . Pada kegiatan akhir, guru me-review kegiatan sebelumnya, agar anak didik mengingat kembali kegiatan pembelajaran yang dilakukan dan memberikan kesimpulan.

Hasil yang diperoleh terhadap nilai moral anak melalui bercerita pada observasi awal jika dibandingkan dengan pelaksanaan siklus I terlihat adanya peningkatan, namun belum mencapai indikator kinerja yang diharapkan, sehingga perlu dilaksanakan siklus II. Hal ini disebabkan pada pelaksanaan siklus I terdapat beberapa kelemahan guru dalam proses pembelajaran dengan bercerita, sehingga perlu dilakukan suatu perbaikan pada siklus II agar indikator kinerja yang diharapkan dapat tercapai. Kelemahan yang terdapat pada siklus I antara lain:

1) Guru masih kurang dalam memberikan motivasi pada anak didik, sehingga anak didik kurang serius dalam mengikuti kegiatan pembelajaran.

2) Guru masih kurang dalam menyampaikan tujuan pembelajaran yang dilakukan.

3) Guru tidak mengorganisir waktu belajar sesuai dengan apa yang telah direncanakan pada skenario pembelajaran.

4) Guru masih canggung dalam pelaksanaan kegiatan pembelajaran, sehingga anak didik belum mampu menggunakan media teks cerita.
Berdasarkan hasil refleksi tersebut kemudian dilakukan langkah-langkah perbaikan pada siklus II sebagai berikut:

1) Guru sudah memberikan motivasi pada anak didik, sehingga anak didik lebih serius dalam mengikuti kegiatan pembelajaran.

2) Guru sudah menyampaikan tujuan berlangsung, guru sudah dapat pembelajaran yang dilakukan.

3) Selama kegiatan pembelajaran mengorganisir waktu belajar sesuai dengan apa yang telah direncanakan pada skenario pembelajaran.

4) Guru sudah tidak canggung lagi dalam pelaksanaan kegiatan pembelajaran, sehingga anak didik sudah mampu menggunakan media teks cerita/ memainkan dengan baik.

Setelah dilakukan perbaikan-perbaikan dalam siklus II, ternyata hasil yang diperoleh mengalami peningkatan yang cukup segnifikan pada aspek kemampuan motorik kasar anak melalui permainan tradisonal bakiak anak. Berdasarkan data yang diperoleh pada siklus I dan siklus II, dapat diketahui perbandingan jumlah anak yang memiliki kemampuan motorik kasar anak dengan criteria Berkembang Sangat Baik (BSB) dan Berkembang Sesuai Harapan (BSH), sebelum tindakan atau observasi awal sebanyak 8 orang anak, setelah pelaksanaan siklus I mengalami peningkatan menjadi 12 anak dan siklus II meningkat menjadi 17 anak, maka dapat dilakukan analisis keberhasilan tindakan secara klasikal dan diperoleh hasil seperti tampak pada diagram berikut ini: 
Gambar 4.2 Diagram Hasil Analisis Mengembangkan Nilai moral anak melalui bercerita.

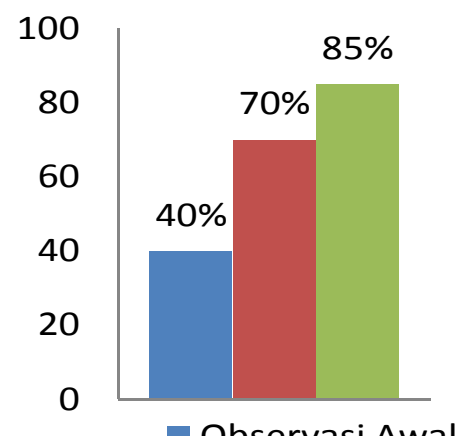

Gambar

Analisis
Mengembangkan Nilai moral anak melalui bercerita. Selama kegiatan penelitian berlangsung, data hasil temuan yang diperoleh sebagaimana dideskripsikan pada halaman sebelumnya, dapat diasumsikan bahwa kegiatan pembelajaran dalam mengembangkan nilai moral anak melalui bercerita yang dirancang, disusun dan dilaksanakan secara baik dan optimal oleh peneliti yang berkolaborasi dengan guru Kelompok B pada setiap pertemuan siklus I dan siklus II sangat memberikan manfaat pada anak didik dengan pengalaman langsung dan konkret, serta hasil belajar dan bermain anak menunjukkan peningkatan. Jika dilihat dari pemahaman anak didik mulai dari pelaksanaan siklus I sebesar $60 \%$ yang jika dibandingkan dengan tahab observasi awal penelitian yang hanya mencapai $40 \%$ dan pada tindakan siklus II mencapai persentase sebesar $85 \%$ yang menunjukkan hasil yang lebih baik dari sebelumnya, karena indikator kinerja yang ditetapkan telah tercapai yaitu minimal $75 \%$ maka penelitian ini dapat dihentikan.

\section{KESIMPULAN}

Berdasarkan hasil observasi dan evaluasi yang telah dilakukan pada anak didik Kelompok B TK Pembina Kota Kendari pada tahun pelajaran 2015/2016, bahwa nilai moral anak melalui bercerita yang dilakukan pada observasi awal anak didik memperoleh nilai ketuntasan secara klasikal sebesar 40\% dimana jumlah anak didik sebanyak 20 anak dan hanya ada 2 orang anak didik yang mendapat nilai bintang $(* * * *)$ atau Berkembang Sangat Baik (BSB) dan 6 orang anak didik yang mendapat nilai bintang $(* * *)$ atau Berkembang Sesuai Harapan (BSH). Pada siklus I mencapai $70 \%$, dimana ada 3 orang anak didik yang memperoleh nilai bintang $(* * * *)$ atau Berkembang Sangat Baik (BSB) dan 9 orang anak didik yang mendapat nilai $(* * *)$ atau Berkembang Sesuai Harapan (BSH). Pada siklus II diperoleh $85 \%$ ketuntasan secara klasikal yaitu 4 orang anak didik yang memperoleh nilai bintang $(* * * *)$ atau Berkembang Sangat Baik (BSB) dan 13 orang anak didik yang mendapat nilai bintang (***) atau Berkembang Sesuai Harapan (BSH).

Berdasarkan analisis data hasil observasi aktivitas mengajar guru pada siklus I ada 15 aspek yang diamati, dari 15 aspek tersebut ada 3 aspk yang tidak tercapai dengan demikian persentase keberhasilan guru terseut sebesar $80 \%$ sedangkan yang tidak tercapai sebesar 20\%. Pada siklus II, persentase ketercapaian aktivitas mengajar guru mengalami peningkatan menjadi $90 \%$ aspek yang dicapai 20, dari 20 aspek tersebut ada 2 aspek yang tidak tercapai sebesar $10 \%$. Berdasarkan hasil analisis tersebut, anak didik dapat 
mengembangkan nilai moral anak melalui metode bercerita pada kelompok B TK Pembina Kota Kendari.

Berdasarkan hasil analisis tersebut, perserta didik dapat mengembangkan hasil belajar nilai moral melalui metode bercerita namun terdapat beberapa anak didik yang masih belum berhasil sehingga hal ini diberikan bimbingan pembelajaran. Dari data tersebut, maka dapat disimpulkan bahwa nilai moral anak dapat ditingkatkan melalui metode bercerita pada kelompok B TK Pembina Kota Kendari. Hal ini ditunjukan dari adanya peningkatan nilai moral anak dari observasi awal sebesar $40 \%$, meningkat pada siklus I menjadi $70 \%$, dan pada siklus II meningkat lagi menjadi $85 \%$.

\section{DAFTAR PUSTAKA}

Ariani, Abdurahman. 1998. Media Pendidika. PT Citra Aditya Bakti.

Depdiknas. 2004. Pedoman Penilaian di Taman Kanak-Kanak. Jakarta: Depdiknas.

Direktorat. 2005. Panduan Pendidikan Anak Usia Dini. Jakarta: Referensi.

Ekawarna. 2013. Penelitian Tindakan Kelas. Edisi Revisi. Jakarta: Referensi.

http://madania.co.id/permainantradisional-sandal-bakiak-anak-isitiga-pasang/
Martinis, Y., Jamilah, S. S. 2013. Panduan Pendidikan Anak Usia Dini. Jakarta: Referensi.

Moeslichatoen R. 1999. Metode Pengajaran di Taman Kanak-Kanak. Jakarta: Rineka Cipta.

Montulalu, B.E.F. dkk. 2010. Bermain dan Permainan Anak. Jakarta: Universitas Terbuka.

Tadkiroatun, Musfiro. 2008. Ceras Melalui Bermain. Jakarta: Grasindo. 2000. Bermain Sambil Belajar dan Mengasah Kecerdasan. Jakarta: Depdiknas.

Samsudin. 1995. Pembelajaran Motorik di Taman Kanak-Kanak. Jakarta: Litera.

Sefrina, Andin. 2013. Deteksi Minat Bakat Anak. Yogyakarta: Media Pressindo.

Sujiono, Bambang. 2007. Metode Pengembangan Fisik. Jakarta: Universitas Terbuka Departemen Pendidikan Nasional.

Sukardi. 2013. Metode Penelitian Pendidikan Tindak Kelas: Implementasi dan Pengembangannya. Jakarta: Bumi Aksara.

Supriadi, Oding. 2013. Perkembangan Peserta Didik. Yogyakarta: Kurnia Kalam Semesta.

Syamsuardi. http://unm-digilib-unmsyamsuardi-86-1-artikel-diakses

Triharsono, Agung. 2013. Permainan Kreatif dan Edukatif untuk Anak Usia Dini. Yogyakarta: Andi.

Wiyani, Novan A. \& Barnawi. 2012. Format PAUD. Yogyakarta: ArRuzz Media.

Yuliaarni, Diah, M. 2014. Peningkatan Kemampuan Motorik Kasar Melalui Permainan Bakiak. Game Bakiak Rice. [online], halaman 7. Tersedia: http://rezkylakora/epa/rice.com.html [20 juli 2015. 